\title{
ANALISIS KINERJA OMBUDSMAN REPUBLIK INDONESIA PERWAKILAN JAWA TENGAH DALAM RANGKA PENANGANAN \\ LAPORAN MASYARAKAT
}

Oleh :

\author{
Dra. Dyah Hariani, MM ${ }^{1}$ Tri Yanti Nur Irson Sitorus ${ }^{2}$ (14020115120015) \\ Departemen Ilmu Administrasi Publik \\ Universitas Diponegoro \\ sitorus.triyanti@gmail.com
}

\begin{abstract}
Maladministration is an inapropriate behavior which is not compatible with the principle of a good public service. Citizens often unsatisfied with the service they received. Number of public service executors do not give the procedural sevice, take too much time, do the illegal extraction, and there are numbers of maladministration happened in public service execution. Indonesian Republic's Ombudsman is a vice Ombudsman in Middle Java fuctioned to monitor and prohibit maladministration in Middle Java. In monitoring, Ombudsman takes action in finishing the report from the citizens through clarification, investigation, and create a conclusion and decision in form of recomendation and suggestion.

The aim of this research is to analyze the work and the factors involves Indonesian Ombudsman's work in Middle Java in handling the report. The theory used in this research is work by considering the Productivity, Service Quality, Responcivity, Responsibility, and Accountability. This research used Qualitative research method with Descriptive data processing. The data was collected by using interview, observation, and documentation. By using core informant as the main sourse and triangulation technique as the source of valid data.

After the research, the Indonesian Republic's Ombudsman in Middle Java is categorized to good. But it can't be said as an optimal one because there are some obstacles in finishing the report for human resources, material, facility, and the agency, and the citizens' undertstanding about Ombudsman right is still bad.
\end{abstract}

Keywords: Performance, Maladministration, Public Service 


\section{PENDAHULUAN}

\section{A. Latar Belakang}

Undang-Undang Nomor 25 Tahun 2009 tentang Pelayanan Publik yang mengatur tentang prinsip-prinsip pemerintahan yang baik yang merupakan efektifitas fungsi-fungsi pemerintahan itu sendiri. Sebagaimana yang tertulis didalam perimbangan UU no 25 tahun 2009 tentang Pelayanan Publik memuat :

"Negara berkewajiban melayani setiap warga negara dan penduduk untuk memenuhi hak dan kebutuhan dasarnya dalam kerangka pelayanan publik yang merupakan amanat Undang-Undang Dasar Negara Republik Indonesia Tahun 1945, membangun kepercayaan masyarakat atas pelayanan publik yang dilakukan penyelenggara pelayanan publik merupakan kegiatan yang harus dilakukan seiring dengan harapan dan tuntutan seluruh warga negara dan penduduk tentang peningkatan pelayanan publik" Pemerintah Pusat maupun daerah/kota berkewajiban untuk memberikan pelayanan yang baik berasaskan pada prinsip clean goverment dan good goverment untuk memberikan pelayanan prima bagi masyarakat, serta bebas dari segala bentuk praktek maladministrasi.

Bentuk-bentuk maladministrasi yang sering kita jumpai adalah penundaan berlarut, penyalahgunaan wewenang, penyimpangan prosedur, pengabaian kewajiban hukum, tidak transparan, kelalaian, diskriminasi, tidak profesional, ketidakjelasan informasi, tindakan sewenang-wenang, ketidakpastian hukum, dan salah pengelolaan. Hal itu menunjukkan masih buruknya pelayanan publik yang diberikan oleh pemerintah, di mana masyarakat tidak mendapatkan pelayanan yang cepat, mudah, nyaman, murah, kepastian biaya, dan terbuka.

Lemahnya pengawasan dalam penyelenggaraan pemerintahan menyebabkan buruknya kinerja aparatur birokrasi dalam memberikan pelayanan publik. Fenomena ini membuat aparatur birokrat cenderung mengabaikan efektivitas dan juga efesiensi dalam memberian pelayanan publik kepada masyarakat yang mengakibatkan buruknya kualitas dari pelayanan publik yang diberikan.Masih sering ditemukannya praktek Korupsi, Kolusi, dan Nepotisme (KKN) dalam birokrasi pemerintah menandakan lemahnya pengawasan terhadap birokrasi pemerintah. Melihat hal ini keberadaan lembaga pengawas eksternal dibutuhkan secara efektif dalam mengontrol tugas Penyelenggaraan negara dan pemerintah seperti lembaga Ombudsman.

Ombudsman RI Perwakilan Jawa Tengah merupakan salah satu lembaga Ombudsman di daerah yang berfungsi untuk mendekatkan pelayanan Ombudsman kepada masyarakat luas di seluruh wilayah Jawa Tengah. Ombudsman Republik Indonesia Perwakilan Jawa Tengah didirikan sejak bulan Oktober tahun 2012, dan telah aktif beroperasi pada tahun 2013. Keberadaan Ombudsman di daerah menjadi perpanjangan tangan dari Ombudsman RI untuk memudahkan kegiatan pengawasan di daerah. Tugas pokok Ombudsman adalah menangani laporan masyarakat menyangkut keputusan atau tindakan administrasi pemerintahan dan pelayanan umum, melindungi orang dari 
pelanggaran hak, penyalahgunaan kekuasaan, kesalahan, pengabaian, keputusan yang tidak adil dan kesalahan administratif. Pembagian tugas antara Ombudsman Pusat dengan daerah diarahkan agar kinerja administrasi pemerintahan dapat diperbaiki dan ditingkatkan sehingga meminimalisir terjadinya bentukbentuk tindakan maladministrasi.

Keberadaan Ombudsman di daerah khususnya di Jawa Tengah pada dasarnya telah mendapatkan respon positif dari masyarakat, meskipun pada kenyataanya masih banyak masyarakat yang belum mengetahui tugas dan fungsi Ombudsman, apalagi nama Ombudsman masih terdengar asing di telinga masyarakat. Masyarakat yang melapor ke Ombudsman RI Perwakilan Jawa Tengah terkait dengan permasalahan dibidang pelayanan publik masih didominasi oleh sebagian daerah khusunya di Kota Semarang. Adapun data Laporan masyarakat yang masuk ke Ombudsman RI Perwakilan Jawa Tengah berdasarkan daerah pelapor, sebagai berikut :

Tabel 1.1

Jumlah Laporan Masyarakat Berdasarkan Daerah Pelapor

\begin{tabular}{|l|l|c|c|c|}
\hline \multirow{2}{*}{ No } & \multicolumn{1}{|c|}{ Kabupaten/ Kota } & $\mathbf{2 0 1 5}$ & $\mathbf{2 0 1 6}$ & $\mathbf{2 0 1 7}$ \\
\cline { 3 - 5 } & & Jumlah & Jumlah & Jumlah \\
\hline 1 & $\begin{array}{l}\text { Kabupaten } \\
\text { Banyumas/Purwokerto }\end{array}$ & 2 & 1 & 4 \\
\hline 2 & Kabupaten Batang & 8 & 3 & 2 \\
\hline 3 & Kabupaten Blora & 1 & 3 & 2 \\
\hline 4 & Kabupaten Demak & 3 & 11 & 11 \\
\hline 5 & Kabupaten Grobogan & 3 & 11 & 6 \\
\hline 6 & Kabupaten Jepara & 3 & 4 & 2 \\
\hline 7 & Kabupaten Kendal & 5 & 3 & 13 \\
\hline 8 & Kabupaten Kudus & 2 & 6 & 4 \\
\hline 9 & Kabupaten Pati & 10 & 8 & 14 \\
\hline 10 & Kabupaten Pemalang & 2 & 0 & 1 \\
\hline 11 & Kabupaten Brebes & 1 & 1 & 0 \\
\hline 12 & Kabupaten Semarang & 5 & 11 & 8 \\
\hline 13 & Kabupaten Tegal & 0 & 1 & 3 \\
\hline 14 & Kota Pekalongan & 2 & 4 & 5 \\
\hline 15 & Kota Salatiga & 4 & 0 & 2 \\
\hline $\mathbf{1 6}$ & Kota Semarang & $\mathbf{5 7}$ & $\mathbf{7 9}$ & $\mathbf{8 9}$ \\
\hline 17 & Kota Tegal & 1 & 2 & 0 \\
\hline 18 & Kota Sleman & 1 & 0 & 3 \\
\hline 19 & Kota Magelang & 0 & 0 & 2 \\
\hline 20 & Kota Surakarta & 0 & 0 & 3 \\
\hline 21 & Kabupaten Cilacap & 1 & 2 & 9 \\
\hline 22 & Kabupaten Boyolali & 0 & 2 \\
\hline 23 & Kabupaten Banjarnegara & & & \\
\hline & & & & \\
\hline
\end{tabular}




\begin{tabular}{|l|l|c|c|c|}
\hline 24 & Kabupaten Karangayar & 4 & 3 & 1 \\
\hline 25 & Kabupaten Kebumen & 1 & 0 & 2 \\
\hline 26 & Kabupaten Klaten & 1 & 2 & 12 \\
\hline 27 & Kabupaten Purbalingga & 1 & 2 & 4 \\
\hline 28 & Kabupaten Wonogiri & 2 & 0 & 0 \\
\hline 29 & Kabupaten Wonosobo & 0 & 4 & 5 \\
\hline 30 & Kabupaten Sukoharjo & 0 & 1 & 5 \\
\hline 31 & Kabupaten Temanggung & 0 & 1 & 2 \\
\hline 32 & Kabupaten Sukabumi & 0 & 1 & 0 \\
\hline 33 & Kabupaten Sragen & 0 & 2 & 6 \\
\hline 34 & Kabupaten Rembang & 0 & 3 & 2 \\
\hline 35 & Kabupaten Purworejo & 0 & 2 & 0 \\
\hline & Jumlah & $\mathbf{1 1 6}$ & $\mathbf{1 7 1}$ & $\mathbf{2 2 9}$ \\
\hline
\end{tabular}

Sumber : Laporan Tahunan Ombudsman RI Jateng tahun 2015-2017

Tabel 1.1 menunjukkan bahwa jumlah laporan yang masuk ke Ombudsman RI Perwakilan Jawa Tengah setiap tahunnya mengalami kenaikan, hal ini berarti kesadaran masyarakat untuk mendapatkan pelayanan publik semakin meningkat serta keberadaan Ombudsman sebagai Lembaga pengawas juga semakin dipercaya oleh masyarakat. Peningkatan jumlah laporan ini disisi lain mengindikasikan bahwa pelayanan publik yang diberikan masih cenderung kurang baik. Jika ditinjau dari jumlah daerah asal pelapor, Kota Semarang merupakan daerah yang paling tinggi melaporkan dugaan maladministrasi ke Ombudsman. Pada tahun 2015 sebanyak 57 laporan, disusul tahun 2016 sebanyak 79 laporan serta tahun 2017 sebanyak
89 laporan, sehingga dari fenomena ini terlihat bahwa dugaan maladministrasi banyak terjadi di wilayah Kota Semarang, namun disatu sisi keberadaan Ombudsman RI Perwakilan Jawa Tengah belum keseluruhan menyentuh wilayah Jawa Tengah, terkhusus wilayah yang jauh dari Kantor Ombudsman mengingat Ombudsman RI Perwakilan Jawa Tengah berada di Kota Semarang.

Ombudsman sebagai Lembaga Pengawas Pelayanan Publik, tugasnya yaitu menerima dan menyelesaikan laporan yang ada. Ombudsman Republik Indonesia Perwakilan Jawa Tengah dari tahun 2015 sampai 2017 setiap tahunnya telah menerima dan menyelesaikan berbagai kasus laporan dari masyarakat. Adapun 
laporan yang telah diselesaikan oleh Ombudsman Perwakilan Jawa Tengah seperti dijelaskan pada tabel berikut ini :

Tabel 1.2

Rekapitulasi Laporan Selesai dan Tidak Selesai

\begin{tabular}{|c|c|c|c|c|c|}
\hline Tahun & $\begin{array}{c}\text { Laporan } \\
\text { Masuk }\end{array}$ & Selesai & \% & Tidak Selesai & \% \\
\hline 2015 & 116 & 34 & $\mathbf{2 9 . 3 \%}$ & 82 & $\mathbf{7 0 . 7 \%}$ \\
\hline 2016 & 171 & 68 & $\mathbf{3 9 . 8 \%}$ & 103 & $\mathbf{6 0 . 2 \%}$ \\
\hline 2017 & 229 & 166 & $\mathbf{7 2 . 5 \%}$ & 63 & $\mathbf{2 7 . 5 \%}$ \\
\hline
\end{tabular}

Sumber : Diolahan dari Laporan Ombudsman RI Jateng 2015-2017

Berdasarkan Tabel 1.2 menjelaskan pada tahun 2015 Ombudsman RI Perwakilan Jawa Tengah hanya mampu menyelesaikan laporan sebanyak 29.3\%, diikuti tahun 2016 laporan yang selesai sebanyak $39.8 \%$, kemudian di tahun 2017 Ombudsman mampu untuk menyelesaikan sebanyak $72.5 \%$ dari laporan yang masuk ke Ombudsman Jawa Tengah. Walaupun secara persentase penyelesaian laporan telah mengalami kenaikan, namun di satu sisi masih terdapatnya laporan masyarakat yang belum terselesaikan oleh Ombudsman RI Perwakilan Jawa Tengah, dengan demikian masi perlu adanya peningkatan kinerja dalam rangka penyelesaian tugas oleh Ombudsman Republik Indonesia Perwakilan Jawa Tengah.
Berdasarkan latar belakang diatas peneliti tertarik untuk mengkaji permasalahan yang timbul dalam penelitian yang berjudul "Analisis Kinerja Ombudsman Republik Indonesia Perwakilan Jawa Tengah dalam rangka Penanganan Laporan Masyarakat"

\section{B. Tujuan}

1. Untuk menganalisis dan mendeskripsikan kinerja Ombusdman Republik Indonesia Perwakilan Jawa Tengah dalam rangka penanganan laporan masyarakat.

2. Untuk menganalisis dan mendeskripsikan faktor pendorong dan penghambat kinerja Ombudsman Republik Indonesia Perwakilan Jawa Tengah. 


\section{Teori}

\section{Administrasi Publik}

Nicholas Henry dalam Pasolong (2008:8) mendefinisikan bahwa administrasi publik merupakan suatu kombinasi yang kompleks antara teori dan praktik dengan tujuan mempromosi pemahaman terhadap pemerintah dalam hubungannya dengan masyarakat yang diperintah, dan juga mendorong kebijakan publik agar lebih responsif terhadap kebutuhan sosial. Administrasi publik berusaha melembagakan praktik-praktik manajemen agar sesuai dengan nilai efektivitas, efisiensi dan pemenuhan kebutuhan masyarakat secara lebih baik.

\section{Manajemen Publik}

Overman dalam Pasolong (2011:33) memberikan penjelasan bahwa manajemen publik merupakan studi interdisipliner dari aspek-aspek umum organisasi, dan merupakan gabungan antara fungsi manajemen seperti planning organizing, dan controlling dari satu sisi, dengan sumberdaya manusia, keuangan, fisik, informasi, dan politik disisi lain. Selanjutnya Overman mengemukakan bahwa manajemen publik bukanlah scientific

\section{Kinerja}

Menurut Armstrong dan Baron (dalam Wibowo, 2013:2) kinerja merupakan tentang apa yang dikerjakan dan bagaimana cara mengerjakannya serta kinerja merupakan hasil menagement, meskipun sangat dipengaruhi olehnya. Manajemen publik bukan policy analysis bukan juga "administrasi publik baru", atau kerangka yang lebih baru. Akan tetapi, manajemen publik merefleksikan tekanantekanan antara orintasi rational-instrumental pada satu pihak dan orientasi politik di pihak lain.

\section{Organisasi}

Anton Athoillah dalam bukunya (2010:170171) memberikan definisi mengenai organisasi menurut beberapa ahli : Prajusi Atmosudirdjo menyebutkan bahwa organisasi merupakan struktur tata pembagian kerja dan struktur tata hubungan kerja antara sekelompok pemegang posisi yang bekerja untuk mencapai tujuan tertentu. Sugandha mengatakan bahwa organisasi adalah sekumpulan manusia yang mempunyai kepentingan yang sama, karena keterbatasan yang mereka miliki, mereka mengikat diri dalam kerja sama pembagian tugas yang jelas meraih kepentingan masing-masing.

pekerjaan yang mempunyai hubungan kuat dengan tujuan strategis organisasi, kepuasaan konsumen, dan memberikan kontribusi ekonomi. Kinerja merupakan ekspresi potensi berupa perilaku seseorang atau kelompok orang dalam 
melaksanakan tugasnya sehingga menghasilkan suatu produk yang merupakan wujud dari semua tugas dan tanggungjawab pekerjaan yang diberikan kepadanya. Penelitian ini lebih mengfokuskan terkait dengan kinerja organisasi, yaitu bagaimana kinerja organisasi Ombudsman Republik Indonesia Perwakilan Jawa Tengah dalam rangka menyelesaikan laporan yang masuk untuk menciptakan pelayanan publik yang baik.

\section{Kinerja Organisasi}

Bastian (dalam Tangkilisan, 2005:175) kinerja organisasi adalah gambaran mengenai tingkat pencapaian pelaksanaan tugas dalam suatu organisasi, dalam upaya mewujudkan sasaran, tujuan, misi dan visi organisasi tersebut. Menurut Wibowo (2013:4) kinerja organisasi juga ditunjukkan oleh bagaimana proses berlangsungnya kegiatan untuk mencapai tujuan tersebut. Didalam proses pelaksanaan aktivitas harus selalu dilakukan monitoring, penilaian, dan review atau peninjauan ulang terhadap kinerja sumber daya manusia.

Menurut Dwiyanto (dalam Sudarmanto, 2014:16) terdapat 5 indikator untuk mengukur kinerja organisasi, yaitu:

a. Produktivitas, dengan mengukur tingkat efisiensi, efektivitas pelayanan, dan tingkat pelayanan publik dalam rangka mencapai hasil yang diharapkan.

b. Kualitas layanan, dengan mengukur kepuasaan masyarakat terhadap layanan yang diberikan.

c. Responsivitas, dengan mengukur kemampuan organisasi untuk mengenali kebutuhan masyarakat, menyusun agenda dan prioritas pelayanan, dan mengembangkan program-program pelayanan publik yang sesuai dengan kebutuhan dan aspirasi masyarakat.

d. Responsibilitas, menjelaskan/mengukur kesesuaian pelaksanaan kegiatan organisasi publik yang dilakukan dengan prinsipprinsip administrasi yang benar atau sesuai dengan kebijakan organisasi.

e. Akuntabilitas, seberapa besar kebijakan dan kegiatan organisasi publik tunduk pada para pejabat politik yang dipilih oleh rakyat atau ukuran yang menunjukkan tingkat kesesuaian penyelenggaraan pelayanan dengan ukuran nilai-nilai atau norma eksternal yang ada di masyarakat atau yang dimiliki para stakeholder.

Menurut Mahmudi (2013:20) faktor-faktor yang mempengaruhi kinerja adalah:

a. Faktor personal/individual meliputi: pengetahuan, keterampilan (skill), kemampuan, kepercayaan diri, motivasi dan komitmen yang dimiliki oleh setiap individu.

b. Faktor kepemimpinan meliputi : kualitas dalam memberikan dorongan, semangat, arahan, dan dukungan yang diberikan manajer dan team leader.

c. Faktor tim meliputi : kualitas dukungan dan semangat yang diberikan oleh rekan dalam satu tim, kepercayaan terhadap sesama anggota tim, kekompakan dan keeretan anggota tim. 
d. Faktor sistem meliputi : sistem kerja, fasilitas kerja atau infrastruktur yang diberikan oleh organisasi, proses organisasi, dan kultur kinerja dalam organisasi.

e. Faktor kontekstual (situasional) meliputi tekanan dan perubahan lingkungan eksternal dan internal.

\section{Metode Penelitian}

Penelitian ini menggunakan metode penelitian kualitatif karena menurut peneliti, penelitan kualitatif merupakan metode yang relevan serta rasional dalam untuk menggambarkan fenomena sosial tertentu. Pendekatan yang dilakukan dalam penelitian ini adalah pendekatan kualitatif yang disajikan secara deskriptif. Penelitian kualitatif yang memusatkan pada sajian deskriptif, menghasilkan data yang yang dibagi kedalam kata-kata dan tindakan, sumber data tertulis, foto serta data statistik. Peneliti menekankan catatan yang menggambarkan situasi sebenarnya guna mendukung penyajian data, khususnya mengenai Penanganan Laporan Masyarakat oleh Ombudsman RI Perwaklan Jawa Tengah. Berdasarkan metode penelitian yang telah dikemukakan diatas, maka data informasi yang diperoleh akan dikelompokkan dan dipisahkan sesuai jenisnya dan dianalisis secara kualitatif.

\section{PEMBAHASAN}

\section{Kinerja Ombudsman Republik Indonesia Perwkailan Jawa Tengah}

Fenomena yang digunakan peneliti untuk menganalisis kinerja Ombudsman RI Perwakilan Jawa Tengah yaitu :

\section{a. Produktivitas}

Produktivitas merupakan kemampuan Ombudsman RI Perwakilan Jawa Tengah dalam hal menyelesaikan tugasnya sesuai dengan visi dan misi yang telah di tetapkan oleh pusat serta berlandaskan oleh Undang-Undang No. 37 Tahun 2008 Tentang Ombudsman Republik Indonesia. Produktivitas juga mampu untuk mengukur tingkat efisiensi dan efektivitas pelayanan Ombudsman RI Perwakilan Jawa Tengah, dan tingkat pelayanan publik dalam rangka mencapai hasil yang diharapkan.

Ombudsman RI Perwakilan Jawa Tengah untuk mengukur produktivitas pegawainya dilihat dari bagaimana Ombudsman mampu untuk melaksanakan tugas dan fungsinya yang diatur dalam Undang-Undang No. 37 Tahun 2008 tentang Ombudsman Republik Indonesia, yakni menyelesaikan laporan masyarakat dan melakukan tugas-tugas pencegahan. Semakin tinggi tingkat penyelesaian laporan maka akan semakin baik pula tingkat produktivitasnya.

Hasil wawancara dengan Elyna selaku Asisten Pratama Ombudsman RI Perwakilan Jawa Tengah, Ombudsman RI Perwakilan Jawa telah menetapkan target penyelesaian laporan. Target tersebut setiap tahunnya ditingkatkan seiring dengan bertambahnya jumlah laporan 
yang masuk ke Ombudsman RI Perwakilan Jawa

Tengah. Jika dilihat dari tingkat penyelesaian laporan yang semakin meningkat memang produktivitas Ombudaman RI Perwakilan Jawa Tengah dari tahun ke tahun memang semakin membaik, namun masih dapat dikatakan belum optimal sebab penyelesaian laporan oleh Ombudsman Republik Indonesia Perwakilan Jawa Tengah belum sampai pada tingkatan $100 \%$, hal tersebut dikarenakan beberapa kendala yang di milik oleh Ombudsman RI Perwakilan Jawa Tengah.

\section{b. Kualitas layanan}

Kinerja pelayanan dapat pula dilihat dari kualitas pelayanan yang diberikan organisasi publik terhadap masyarakat. Karna sekarang ini, kualitas layanan menjadi penting dalam menjelaskan kinerja organisasi pelayanan publik. Penilaian kualitas pelayanan ditentukan oleh pengguna jasa pelayanan tersebut, pengguna saja akan menilai dengan membandingkan pelayanan yang mereka terima dengan yang mereka harapkan.

Kualitas pelayanan yang diberikan oleh Ombudsman RI Perwakilan Jawa Tengah dapat di lihat melalui kepuasan masyarakat terhadap layanan yang diberikan, baik itu saat Ombudsman menerima, menindaklanjuti, serta menyelesaikan laporan dari masyarakat. Kualitas Layanan Ombudsman dapat juga dilihat melalui jumlah laporan yang dari tahun ketahun yang selalu mengalami kenaikan. Hal ini berarti Ombudsman telah dapat dipercaya oleh masyarakat luas sebagai lembaga pengawas dalam hal memperbaiki kualitas layanan oleh penyelenggara pelayanan publik melalui penyelesaian laporan masyarakat. Hasil wawancara dengan Tulus sebagi pelapor atas kasus tanah miliknya yang terkena proyek pembangunan jembatan. Tulus sangat puas dengan pelayanan yang diberikan oleh Ombudsman RI Perwakilan Jawa Tengah karena telah membantu dirinya untuk menyelesaikan kasus tanah miliknya.

\section{c. Responsivitas}

Responsivitas dapat dilihat dari tindakan yang dilakukan Ombudsman Republik Indonesia Perwakilan Jawa Tengah dalam menerima laporan/pengaduan masyarakat atas dugaan tindakan maladministrasi dalam penyelenggaraan pelayanan publik. Omubdsman RI Perwakilan Jawa Tengah dalam hal ini telah menerima laporan/pengaduan masyarakat dengan baik, memeriksa laporan serta melakukan pemeriksaan substantif telah sesuai dengan prosedur penyelesian laporan.

Responsivitas mampu untuk mengukur kemampuan Ombudsman RI Perwakilan Jawa Tengah untuk mengenali kebutuhan masyarakat, menyusun agenda dan prioritas pelayanan, dan mengembangkan program-program pelayanan publik yang sesuai dengan kebutuhan dan aspirasi masyarakat.

Ombudsman RI Perwakilan Jawa Tengah dalam merespon kebutuhan masyarakat yaitu dengan melakukan tindakan-tindakan untuk memuasakan masyarakat, serta memberikan kemudahan kepada masyarakat melalui dialog interaktif di media-media seperti media suara, media televisi, maupun media cetak. Kemudahan 
tersebut mempukan Ombudsman untuk mengenali kebutuhan dan masalah yang terjadi di masyarakat, dengan demikian tindakan yang dilakukan oleh Ombudsman RI Perwakilan Jawa Tengah yaitu dengan mengadakan Investigasi atas prakarsa sendiri. Investigasi ini dilakukan Ombudsman untuk melihat apakah instansi pemberi pelayanan telah melakukan pelayanannya sesuai dengan asas-asas pelayanan publik.

\section{d. Responsibilitas}

Responsibilitas Ombudsman RI Perwakilan Jawa Tengah dapat dilihat dari bagaimana cara ombudsman dalam menindaklanjuti laporan/ pengaduan dari masyarakat. Ombudsman melakukan koordinasi dan kerjasama dengan para lembaga negara atau lembaga pemerintahan lain serta lembaga kemasyarakatan dan perseorangan. Koordinasi yang dilakukan yaitu dalam rangka penyelesaian laporan, yakni meminta keterangan baik secara lisan maupun secara tertulis kepada pelapor, terlapor atau pihak yang terkait dengan laporan yang diadukan.

Ombudsman memberikan pemahaman kepada para instansi-instansi, dan masyarakat bahwa Ombudsman merupakan lembaga negara yang berfungsi untuk mengawasi penyelenggaraan pelayanan publik yang diberikan oleh instansi-instansi pemerintah, baik itu BUMD, BUMN, Badan Swasta dan Perseorangan, dengan memberikan pemahamanpemahan seperti itu harapannya pelayanan yang diberikan oleh Ombudsman tepat sasaran bagi masyarakat yang membutuhkan.
Pada kenyataannya Ombudsman masih sangat asing di telinga para masyarakat, dengan begitu Ombudsman RI Perwakilan Jawa Tengah melakukan berbagai cara agar dapat memperkenalkan diri di kalangan masyarakat. Salah satu cara yang dilakukan Ombudsman yaitu dengan menggandeng Konco Ombudsman, atau sahabat Ombudsman. Harapannya dengan adanya para Konco Ombudsman dapat membantu Ombudsman RI Perakilan Jawa Tengah untuk memberikan pemahaman mengenai Tugas, Pokok dan Fungsi Ombudsman RI perwakilan Jawa Tengah. Bukan hanya itu saja, Ombudsman RI Perwakilan Jawa Tengah dalam rangka memperkenalkan diri kepada masyarakat yaitu dengan menggandeng para Universitas. Ombudsman mengadakan sosialisasi dan perlombaan-perlombaan yang mengajak mahasiswa untuk lebih mengetahui pelayanan publik yang baik harapannya nama Ombudsman dapat lebih dikenal di berbagai daerah, namun memang tidak dapat dipungkiri bahwa masih banyak masyarakat yang belum mengetahui tugas dan kewenangan Ombudsman. Terbukti saat masyarakat yang datang untuk melaporkan kasus pelayanan yang dialaminya, namun ternyata kasus tersebut bukan didalam lingkup kewenangan Ombudsman.

\section{e. Akuntabilitas}

Akuntabilitas dalam hal ini merupakan bentuk pertanggung jawaban organisasi terhadap hasil yang dicapai, pelaksanaan tugas dan kinerja organisasi tertuang dalam laporan kinerja organisasi tersebut. Pengertian akuntabilitas mengandung aspek bahwa publik mempunyai 
hak untuk mengetahui kebijakan-kebijakan yang di ambil oleh para pemimpin yang dipercayainya. Pertanggung jawaban dalam hal akuntabilitas tidak terbatas oleh laporan pertanggungjawaban saja, namun juga soal kemudahan masyarakat untuk mendapatkan informasi tersebut baik secara lisan maupun tulisan.

Ombudsman Republik Indonesia perwakilan Jawa Tengah memiliki laporan pertanggungjawaban berupa laporan berkala dan laporan tahunan. Laporan berkala disampaikan setiap tiga bulan sekali, kemudian laporan tahunan merupakan laporan yang disampaikan pada bulan pertama tahun berikutnya. Laporan ini merupakan bentuk pertanggungjawaban Ombudsman RI Perwakilan Jawa Tengah yang bersifat kelembagaan yang dimana Ombudsman RI Perwakilan Jawa Tengah melaporkan hasil kinerjanya kepada Ombudsman Republik Indonesia.

Ombudsman sebagai lembaga vertikal wajib untuk menyampaikan laporannya kepada Ombudsman pusat, selanjutnya Ombudsman pusat akan mengakumulasi serta mempublikasikan laporan dari setiap perwakilan Ombudsman ke publik. Penyampaian laporan ini merupakan sebagai bentuk pertanggungjawaban secara kelembagaan yang dilakukan oleh Ombudsman RI Perwakilan Jawa Tengah untuk menjaga akuntabilitas kelembagaannya.

Ombudsman RI Perwakilan Jawa Tengah sebagai pelayan publik tentunya mempunyai kewajiban untuk mempertanggungjawabkan semua amanat yang diterima dari masyarakat, baik itu dalam hal perkembangan penanganan laporan serta hasilnya. Pertanggungjawaban ini sangat penting untuk di komunikasikan kepada masyarakat, mengingat hakikat dari akuntabilitas itu sendiri. Masyarakat mempunyai hak untuk mengetahui kebijakan maupun keputusan yang diambil oleh organisasi penyelenggara kebijakan publik. Bentuk pertanggungjawaban ini tidak hanya sebatas laporan semata namun juga kemudahan masyarakat untuk mengakses laporan pertanggungjawaban tersebut.

Ombudsman RI Perwakilan Jawa Tengah pada faktanya telah mempertanggungjawabkan kinerja kepada publik khususnya masyarakat Jawa Tengah. Laporan Hasil Akhir Pemeriksaan merupakan laporan yang di informasikan kepada pelapor atas khasus yang di laporkannya. Ombudsman RI Perwakilan Jawa Tengah dalam hal penyelesaian laporan sedemikian mungkin untuk menyampaikan perkembangan hasil pemeriksaan baik melalui via surat maupun via telepon kepada pelapor. Ombudsman RI Perwakilan Jawa Tengah telah melaksanakan bentuk pertanggungjawaban secara eksternal kepada publik. Publik dapat lebih mudah untuk mengakses laporan pertanggungjawaban Ombudsman RI Perwakilan Jawa Tengah melalui media elektronik berupa web, medua suara, maupun media cetak. 


\section{Faktor-faktor yang mempengaruhi} Kinerja Ombudsman RI Perwakilan Jawa Tengah

Kinerja Ombudsman Republik Indonesia Perwakilan Jawa Tengah dipengaruhi oleh beberapa faktor berikut :

\section{a. Faktor personal/individual}

Faktor sumberdaya manusia merupakan hal yang terpenting dalam sebuah organisasi. Tak tersedianya sumberdaya yang memadai akan menghambat pencapaian tujuan organisasi tersebut, dan berpengaruh pada produktivitas organisasi itu sendiri.

Sumberdaya manusia atau pagawai yang terdapat di Ombudsman RI Perwakilan Jawa Tengah sejumlah 17 pegawai, terdiri dari 1 (satu) menjabat sebagai kepala perwakilan, 13 (tigabelas) sebagai asisten yang bertugas untuk menyelesaikan laporan dari masyarakat, 4 (empat) dari sekretariat jendral. Sekretariat jendal berfungsi untuk membantu asisten perwakilan untuk menyelesaikan tugas seperti yang diamanatkan di dalam Undang-Undang Ombudsman RI.

Keterbatasan sumberdaya manusia yang dimiliki Ombudsman RI Perwakilan Jawa Tengah menjadi penghambat dalam penyelesaian tugas dan fungsi mereka. Ombudsman RI Perwakilan Jawa Tengah dengan jumlah SDM yang sangat minim harus mengawasi $35 \mathrm{kab} / \mathrm{kota}$ di wilayah Jawa Tengah, hal tersebut menjadikan Ombudsman RI Perwakilan Jawa Tengah kewalahan dalam proses penyelesian tugas mereka, terkhusus tugas dalam rangka penyelesaian laporan masyarakat.

\section{b. Faktor kepemimpinan}

Kepemimpinan menjadi faktor yang mempengaruhi kinerja Ombudsman RI Perakilan Jawa Tengah. Kepala Perwakilan mempunyai peranan untuk menjaga koordinasi baik itu kepada instansi/ lembaga penyelenggara pelayanan, masyarakat dan juga menjaga integritas organisasi. Kepala Perwakilan mengambil suatu pilihan yang menjadi alternative dalam rangka pemecahan masalah dalam proses penyelesaian laporan masyarakat.

\section{c. Faktor Tim}

Faktor Tim mempengaruhi kinerja Ombudsman RI Perwakilan Jawa Tengah, dukungan, motivasi dan semangat yang diberikan oleh Pemimpin dan antar rekan Asisten merupakan salah satu cara agar Ombudmsna RI Perwakilan Jawa Tengah mampu untuk menyelesaikan amanah dan tugas yang diembanya.

Ombudsman RI Perwakilan Jawa Tengah sering mengadakan diskusi dan bedah Laporan, yang dimana kendala dalam rangka penanganan laporan bersama-sama dicari alternatif penyelesaiannya, sehingga laporan dugaan maladministrasi yang masuk ke Ombudsman bukan hanya di selesaikan oleh satu asisten saja namun secara bersama untuk di selesaikan sehingga tujuan dan target yang telah ditetapkan Ombudsman dapat terwujud.

\section{d. Faktor sistem}

Faktor sistem dalam hal ini meliputi sistem kerja, yang dimana sistem kerja yang ada di 
Ombudsman RI Perwakilan Jawa Tengah bersifat terbuka dan legaliter, sehingga antara kepala perwakilan dan asisten serta staff sekretariat jendral jaraknya tidak terlalu jauh dengan begitu kultur yang terjalin lebih bersifat kekeluargaan.

Sarana dan prasarana yang dimiliki oleh Ombudsman RI Perwakilan Jawa Tengah menurut wawancara belum mendukung dalam proses penyelesian laporan. Gedung Kantor Ombudsman RI Perwakilan Jawa Tengah masih sistem kontrak tahunan yang dimana Ombudsman RI Perwakilan Jawa Tengah belum memiliki gedung menetap sebagai Kantor mereka. Gedung yang digunakan pun masih belum memiliki fasilitas pelayanan publik yang baik, dilihat dari Toiletnya yang tidak memiliki fasilitas pelayanan khusus difabel. Ombudsman dalam proses pengawasannya juga memerlukan alat investigasi, namun pada kenyataanya alat yang dimiliki oleh Ombudsman RI Perwakilan Jawa Tengah juga belum mampu untuk menunjang kemudahan mereka saat menjadi pengawas. Anggaran Ombudsman masih menjadi hambatan dalam proses penyelesaian tugas. Menurut Fajar bagian keuangan Ombudsman mengatakan bahwa anggaran yang dimiliki setiap tahunnya masih menjadi kendala dalam rangka penyelesaian tugas Ombudsman.

\section{e. Faktor kontekstual (situasional)}

Faktor ini melihat bagaimana lingkungan sosial mempengaruhi kinerja Ombudsman RI Perwakilan Jawa Tengah. Lingkungan sosial itu sendiri terlihat dari respon instansi dan masyarakat terhadap Lembaga Ombudsman RI Perwakilan Jawa Tengah. Instansi penyelaggara pelayanan sebagian besar merasa terbantu dengan adanya Ombudsman RI Perwakilan Jawa Tengah, sebab instansi merasa dengan hadirnya Ombudsman terkhusus di wilaah Jawa Tengah maka instansi tersebut lebih disadarkan dan lebih membenahi diri untuk memberikan pelayanan yang baik kepada masyarakat.

Jika dilihat dari jumlah laporan yang masuk setiap tahunnya yang semakin lama semkin meningkat berarti masyarakat mulai mengetahui dan mempercayai Ombudsman, namun disatu sisi juga masih banyak masyarakat yang belum mengetahui Tupoksi dari Ombudsman itu sendiri. Hasil wawancara dengan Bellinda sebagai Asisten Ombudsman, banyak masyarakat yang datang ke Ombudsman namun instansi yang dilaporkannya tidak dalam ranah kewenangan Ombudsman, sehingga dengan demikian masih perlunya sosialisasi dan pengenalan Ombudsman kepada masyarakat di seluruh Jawa Tengah. 


\section{PENUTUP}

\section{a. Kesimpulan}

Kinerja Ombudsman RI Perwakilan Jawa Tengah dalam rangka penyelesaian laporannya jika dilihat dari kualitas layanan, responsivitas, responsibilitasnya sudah dapat dikatakan baik dan berjalan sesuai dengan alur penyelesaian laporan/pengaduan meskipun jika dilihat dari produktivitasnya belum mampu mencapai target penyelesaian laporan.

Ombudsman pada prakteknya telah melaksanakan tugas sebagaimana yang telah diamanatkan oleh Undang-Undang No. 37 Tahun 2008 tentang Ombudsman Republik Indonesia yakni menerima laporan, menindaklanjutinya serta melakukan pencegahan. Ombudsman juga telah melakukan pertanggungjawaban secara kelembagaan berupa laporan berkala dan laporan tahunan kepada Ombudsman Pusat. Laporan pertanggungjawaban tersebut juga dapat dengan mudah di akses oleh masyarakat melalui media elektronik seperti akun web resmi Ombudsan Republik Indonesia, serta media cetak.

Kinerja Ombudsman RI Perwakilan Jawa Tengah dipengaruhi oleh beberapa faktor yakni faktor personal/SDM, kepemimpinan, tim, sistem, dan kontekstual. Ombudsman RI Perakilan Jawa Tengah masih terkendala oleh SDM, anggaran serta sarana dan prasarana yang terbatas. Masyarakat Jawa Tengah juga masih banyak yang belum mengetahui tugas, fungsi dan kewenangan Ombudsman apalagi masyarakat yang bertempat tinggal di luar Kota Semarang.

\section{b. Saran}

1. Meningkatkan sosialisasi sampai kepada masyarakat yang jauh dari Kota Semarang agar seluruh masyarakat di Provinsi Jawa Tengah mengetahui tugas, fungsi, kewenangan serta tindakan yang termasuk pelanggaran pelayanan publik.

2. Perlu adanya pendampingan dan pelatihan rutin bagi semua asisten di Perwakilan Ombudsman agar kualitas secara sumber daya manusia di Ombudsman menjadi mumpuni dan ahli dalam proses penanganan laporan masyarakat.

3. Mengembangkan kerja sama dengan instansi atau lembaga pelayanan publik agar instansi/ lembaga tersebut segera menindaklanjuti hasil temuan atau produk Ombudsman.

4. Perlu adanya perwakilan Ombudsman yang berada di Kabupaten/kota sehingga masyarakat desa yang bertempat tinggal jauh dari Ibu Kota Provinsi lebih merasakan kehadiran Ombudsman.

\section{DAFTAR PUSTAKA}

\section{Sumber Buku :}

Athoillah, Anton. 2010. Dasar-dasar Manajemen. Bandung: CV Pustaka Setia

Mahmudi. 2015. Manajemen Kinerja Sektor Publik. Yogyakarta: UPP AMP YKPN.

Moleong, J. Lexy. 2010. Metodologi Penelitian Kualitatif. Bandung: PT Remaja Rosdakarya.

Pasolong, Harbani. 2008. Teori Administrasi Publik. Bandung: Alfabeta. 
Tangkilisan, Hessel Nogi. 2005. Manajemen Publik. Jakarta: Gramedia Widia.

Wibowo. 2013. Manajemen Kinerja. Jakarta: Rajawali Pers.

\section{Undang-Undang :}

Undang-Undang No. 25 Tahun 2009 Tentang Pelayanan Publik

Undang-Undang No. 37 Tahun 2008 Tentang Jurnal : Ombudsman Republik Indonesia

Latang, Amelia. 2014. Analisis Kinerja Organisasi Pada Kantor Pelayanan Perizinan Terpadu Daerah Provinsi Sulawesi Tengah. Universitas Tadulako, Palu : e-Jurnal Katalogis. Vol. 2 No. 1 Hal. 71-79.

Marbun, Fibrisio H. 2016. Kinerja Ombudsman Republik Indonesia Perwakilan Provinsi Riau dalam Penangana Laporan Masyarakat Kota Pekanbaru.
Universitas Pekanbaru, Riau: Jurnal Onliine Mahasiswa FISIP. Vol. 3 No. 2 Hal. 1-11.

Sianipar, Agahari Abadi, dkk. 2016. Analisis Kinerja Dinas Kebudayaan dan Pariwisata Provinsi Jawa Tengah. Universitas Diponegoro, Semarang: Journal of Public Policy and Management Review. Vol. 5, No. 2, Hal. 1-15

\section{Sumber Lain :}

Laporan Tahunan Ombudsman Republik Indonesia Perwakilan Jawa Tengah Tahun 2015

Laporan Tahunan Ombudsman Republik Indonesia Perwakilan Jawa Tengah Tahun 2016

Laporan Tahunan Ombudsman Republik Indonesia Perwakilan Jawa Tengah Tahun 2017 